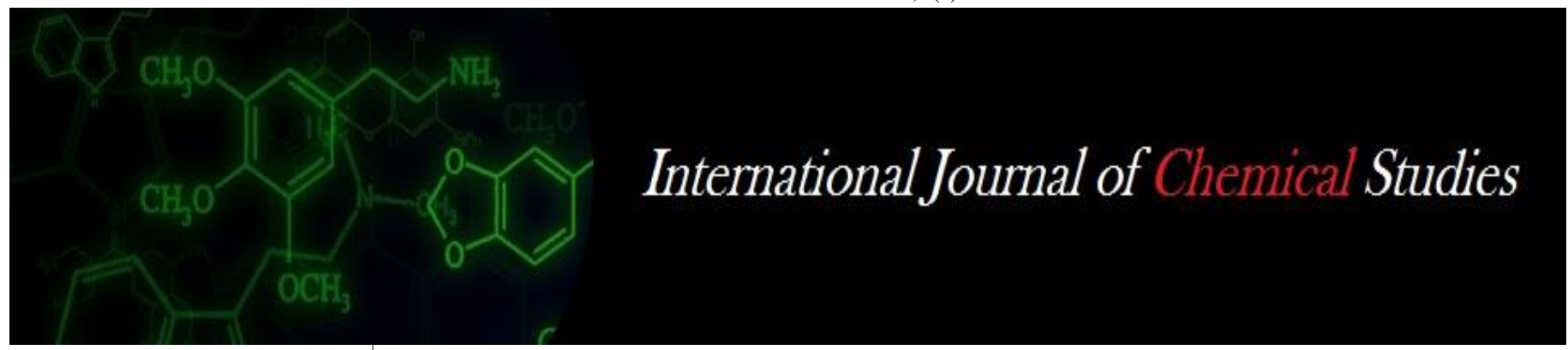

P-ISSN: 2349-8528

E-ISSN: 2321-4902

www.chemijournal.com

IJCS 2020; 8(2): 1293-1296

(C) 2020 IJCS

Received: 09-01-2020

Accepted: 13-02-2020

Bhanupratap Singh Sikarwar School of Agriculture, ITM

University, Gwalior, Madhya

Pradesh, India

M Devender Reddy

M.S. Swaminathan School of Agriculture, Centurion

University of Technology and

Management, Paralakhemundi,

Odisha, India

Girish Pandey

School of Agriculture, ITM

University, Gwalior, Madhya

Pradesh, India

Mahesh Singh

School of Agriculture, ITM

University, Gwalior, Madhya

Pradesh, India

\section{Response of wheat (Triticum aestivum L.) varieties to different levels of nitrogen under rain fed condition}

\author{
Bhanupratap Singh Sikarwar, M Devender Reddy, Girish Pandey and \\ Mahesh Singh
}

DOI: https://doi.org/10.22271/chemi.2020.v8.i2t.8943

\begin{abstract}
An experiment on response of wheat (Triticum aestivum L.) varieties to different levels of nitrogen under rain fed condition was conducted at ITM University Gwalior (M.P.) to find at the optimum levels of nitrogen and suitable wheat varieties to grid region of Madhya Pradesh. Three levels of nitrogen (40, 60 and $80 \mathrm{Kg} \mathrm{ha}^{-1}$ ) in main plot and four Varieties (PBW613, C-306, PBW644 and PBW660) in sub plots were tested in split plot design with four replications. Number of plants per meter length, plant height, dry matter, and days to maturity; number of ear heads $\mathrm{m}^{-1}$ row length, spike length, number of spike lets per spike, grains per spike and grain weight per spike, and grain, straw and biological yield increased significantly with increase in nitrogen level from 40 to $60 \mathrm{Kg} \mathrm{ha}^{-1}$. Among varieties maximum shoot length, dry weight accumulation, number of grain spike ${ }^{-1}$, weight of grain spike, ${ }^{-1}$ length of spike and grain and straw yield and biomass was observed in variety $\mathrm{C} 306$ as compared to all other varieties. For the grid region of northen Madya Pradesh, growing of wheat variety $\mathrm{C} 306$ with $60 \mathrm{Kg} \mathrm{N}^{-1}$ under rain fed condition found promising.
\end{abstract}

Keywords: Wheat varieties, nitrogen levels, grain yield, yield attributes

\section{Introduction}

Amongst cereals, wheat (Triticum aestivum L.) is the most important staple food grain crop in Indian diet and main source of protean and calories for a large section of population and occupies an area of 30.5 million ha. Besides staple food for human being, wheat straw is a good source of feed for a large population in our country (Jaiswal, 2009). The India's share in world wheat area is about $13.77 \%$, whereas it occupies $13.19 \%$ share in the world wheat production.

Different factors responsible for higher productivity are use of high yielding cultivars, use of fertilizers and irrigation. One of the major essential elements for growth and development of plants is nitrogen. Yield increase in wheat was observed up to $120 \mathrm{~kg} \mathrm{ha}^{-1}$ of applied nitrogen (Singh and singh, 1991, Sharma and Dhillon, 1993 and Jat et al., 2014) ${ }^{[1]}$. Excess nitrogen, in particular, is also not good for wheat crop; it causes an early exhaustion of soil moisture, induces lodging, and reduces resistance to leaf diseases, and delay in maturity.

Genotypes play a vital role in crop production. The choice of right genotype of wheat helps to augment crop productivity by about 20-25 per cent. Any genotype of wheat before recommended for general cultivation for particular region has to be judged for its potential, tolerance against disease in general and in responsiveness to added water and fertilizer. Further, to reduce the impact of nutrient deficiency on cereal production, the selection of genotypes that are superior in the utilization of available nutrients either due to enhanced uptake capacity or because of more efficient use of the absorbed nutrients in grain production is desirable (Mishra et al. 2015).

Keeping these points in view, present study was conducted to determine the growth and yield response of wheat varieties to different levels nitrogen. 


\section{Material and Methods}

An experiment was conducted at ITM University, Gwalior, Madhya Pradesh on Response of wheat (Triticum aestivum L) varieties to different levels of nitrogen under rain fed condition during rabi season of 2015-16. The experiment comprised of three nitrogen levels - 40,60 and $80 \mathrm{~kg} \mathrm{ha}^{-1}$ and four varieties - PBW 613, C-306 (C), PBW 644 and PBW 660 which were tested in split plot design with nitrogen levels in main plots and varieties in sub plots replicated four times.

The experiment site falls under humid sub-tropical climate and located in between $23^{\circ} 10^{\prime} \mathrm{N}$ latitude and $79^{\circ} 54^{\prime} \mathrm{E}$ longitudes at an elevation of 411.98 meters above mean sea level. The soil type of experimental field was sandy loam in nature with $\mathrm{pH}$ of 7.4 and EC $0.29 \mathrm{dsm}-1$, having $242 \mathrm{~kg}$ available nitrogen, $20.5 \mathrm{~kg}$ available phosphorus and $456 \mathrm{~kg}$ available potassium.

During the crop growth period, the maximum temperature varied between $18.9{ }^{\circ} \mathrm{C}$ in January third week to $40.1{ }^{\circ} \mathrm{C}$ in April first week and minimum temperature ranged from 3.9 ${ }^{\circ} \mathrm{C}$ in third week of December to $23{ }^{\circ} \mathrm{C}$ in second week of April.

The experimental field was given a pre-sowing irrigation and two ploughings were done by tractor and this was followed by planking each time. Then the field was laid out into plots with appropriate bunds between treatments. The sowing of wheat varieties was done in furrows $5 \mathrm{~cm}$ deep at a distance of 20 $\mathrm{cm}$ on Nov 2, 2015 with $125 \mathrm{~kg}$ seed ha-1 and harvested on April 6, 2016. The sowing was done with the help of kudali and seeds were covered by planking. First weeding was done at 30 days after sowing with the help of khurpi, hand hoe. Entire quantity of phosphorus $\left(30 \mathrm{~kg} \mathrm{P}_{2} \mathrm{O}_{5} \mathrm{ha}^{-1}\right)$ was given through DAP $\left(18 \% \mathrm{~N}\right.$ and $\left.46 \% \mathrm{P}_{2} \mathrm{O}_{5}\right)$ and potassium $(20 \mathrm{~kg}$ $\mathrm{K}_{2} \mathrm{O}$ ha $\left.^{-1}\right)$ through MOP $\left(60 \% \mathrm{~K}_{2} \mathrm{O}\right)$. The nitrogen was made as per treatments of nitrogen levels through urea $(46 \% \mathrm{~N})$ at sowing by taking in to account of $\mathrm{N}$ supplied through DAP.

All the agronomic management practices were done uniformly in all the treatments. The observations on plant height, numbers of tiller per meter row length and the yield contributing characters viz., ear head $\mathrm{m}^{-1}$ row length, spike length $(\mathrm{cm})$, number of spike lets spike ${ }^{-1}$, number of grains spike $^{-1}$, grain weight spike $^{-1}(\mathrm{~g})$ and 1000 grains weight $(\mathrm{g})$ and the biological, grain and straw yields were recorded as per standard procedures.

The Harvest Index, the ratio of economic yield to the biological yield was calculated and expressed in per centage as given below

$$
\text { Harvest Index }(\%)=\frac{\text { Economic yield (grain yield) }}{\text { Biological yield }(\text { grain }+ \text { straw) }} \times 100
$$

The data obtained on various observations were subjected to statistical analysis by using the techniques of the analysis of variance (ANOVA) and the treatment was tested by $\mathrm{F}$ test and Critical difference (CD) at 5\% level of significance (Panse and Sukhatme, 1989) for each character to compare the differences among treatment means.

\section{Results and Discussion Nitrogen levels}

At harvest, the plant height and tiller number per meter row length was significantly higher with application of $80 \mathrm{~kg} \mathrm{~N}$ $\mathrm{ha}^{-1}$ over $40 \mathrm{~kg} \mathrm{~N}^{-1}$ and comparable with $60 \mathrm{~kg} \mathrm{~N} \mathrm{ha}^{-1}$. These parameters recorded with $60 \mathrm{~kg} \mathrm{~N} \mathrm{ha}^{-1}$ were comparable with those observed with $40 \mathrm{~kg} \mathrm{~N}^{-1}$. Days to maturity noted with 80 and $60 \mathrm{~kg} \mathrm{~N} \mathrm{ha}^{-1}$ were comparable with each other and significantly superior over $40 \mathrm{~kg} \mathrm{~N} \mathrm{ha}^{-1}$. The number of ear head per $\mathrm{m}$ row length, spike length, number of spike lets per spike and number of grains per spike observed with 60 and $80 \mathrm{~kg} \mathrm{~N} \mathrm{ha}{ }^{-1}$ was comparable and significantly superior over that received $40 \mathrm{~kg} \mathrm{~N} \mathrm{ha}^{-1}$.

The grain weight per spike was significantly higher at $80 \mathrm{~kg}$ $\mathrm{N}^{-1}$ over $60 \mathrm{~kg} \mathrm{~N} \mathrm{ha}^{-1}$ which in turn recorded significantly higher grain weight over $40 \mathrm{~kg} \mathrm{~N} \mathrm{ha}^{-1}$. The 1000 grain weight was significantly higher at $40 \mathrm{~kg} \mathrm{~N}$ ha-1 over $80 \mathrm{~kg} \mathrm{~N}$ ha-1 and comparable with of $60 \mathrm{Kg} \mathrm{N} \mathrm{ha}^{-1}$. The 1000 grain weight recorded with latter level of $\mathrm{N}$ was comparable with $80 \mathrm{Kg} \mathrm{N}$ $\mathrm{ha}^{-1}$.

The biological and grain yield observed with 60 and $80 \mathrm{~kg} \mathrm{~N}$ $\mathrm{ha}^{-1}$ was comparable with each other and significantly superior over that received $40 \mathrm{~kg} \mathrm{~N} \mathrm{ha}^{-1}$. The straw yield was significantly higher at $80 \mathrm{~kg} \mathrm{~N} \mathrm{ha}^{-1}$ over $40 \mathrm{~kg} \mathrm{~N} \mathrm{ha}^{-1}$ and comparable with $60 \mathrm{~kg} \mathrm{~N}^{-1}$. The straw yield recorded with latter treatment was comparable with $40 \mathrm{~kg} \mathrm{~N} \mathrm{ha}^{-1}$. The harvest index increased with $\mathrm{N}$ level from 40 to 60 and $80 \mathrm{~kg}$ $\mathrm{N} \mathrm{ha}^{-1}$.

The grain yield increased with increase in levels of nitrogen. The yield of wheat is generally based upon two major factors i.e. yield per plant and effective shoot per unit area, while the yield per plant is based upon the number of effective shoots $\mathrm{m}^{-1}$ row length, spike length, number of spikelets spike ${ }^{-1}$, number of grains spike ${ }^{-1}$, weight of grains spike ${ }^{-1}$ and test weight which improved with increase in the level of $\mathrm{N}$. These yield contributing characters influenced the grain yield which in turn, was responsible for higher seed yield per hectare with increasing levels of nitrogen. These results corroborate with the findings of Yadav et al. (2012) [9], Puniya et al. (2015) ${ }^{[6]}$ and Singh (2015) ${ }^{[8]}$.

Bio-mass and straw yields increased with increase in levels of nitrogen. An increase in nitrogen level was found closely associated with the simultaneous increase in bio-mass and straw production. It is obvious that dry matter is a net saving of photosynthesis and essential for the building up of plant organs, which ultimately reflect on bio-mass and straw production. Hence, nitrogen is quite responsible for higher bio-mass yield, seed and straw production. Similar results have been reported by Kachroo and Razdan (2006) ${ }^{[2]}$, Yadav et al. (2012) ${ }^{[9]}$ and Phogat et al. (2014).

\section{Varieties}

The number of tillers per meter row length was significantly higher in variety C 306 over other varieties PBW613, PBW644 and PBW660. The height of varieties C306 and PBW 613 varieties was higher than that of PBW 660 and PBW 644. Among varieties tested, C 306 took significantly more days to maturity as compared to PBW 644 and PBW 660 . The number of days to maturity was comparable between varieties C306 and PBW 613.

Among different varieties tested, number of ear head $\mathrm{m}^{-1}$ row length of C 306 was comparable with each other and significantly superior over PBW 644 and PBW 660 varieties and comparable with PBW 613.

The length of spike and number of spike lets per spike recorded with $\mathrm{C} 306$ and PBW 613 were found to be significantly superior as compared to PBW 660 and PBW 644. The number of grains per ear head was significantly higher in C 306 over PBW 613 which in turn recorded significantly higher number of garins per ear head over PBW 660 and PBW 644. The grain weight and 1000 grain weight observed with C 306 was comparable with that of PBW 613 
and significantly superior over PBW 660 and PBW 644. The variety PBW 644 recorded significantly lower weight of panicle and 1000 grain weight as compared to PBW 644.

The biological and grain yield of variety C 306 was significantly higher over PBW 613 which in turn recorded significantly higher yield over PBW 660 and PBW 644. The biological yield of PBW 660 was significantly higher than that of PBW 644 and the grain yield was comparable between these varieties. The straw yield of variety C 306 and PBW 613 was comparable with each other and significantly superior over PBW 660 and PBW 644. Among the latter two varieties, PBW 660 recorded significantly higher straw yield over PBW 644. The highest harvest index (41.61\%) was obtained with variety C 306 followed by Variety PBW 644, PBW 660 and PBW 613.

The varieties tested in the present investigation behaved differently. Significant variations in growth characters were observed. The effective development of plant parts and dry matter production of varieties are prerequisite for better expression of its inherent potential to produce the economic sink. The reason for accumulation of more dry matter in $\mathrm{C}$ 306 variety may be due to its superior growth characters such as plant height and number of shoots. The variety C 306 produced higher grain yield followed by PBW 613 as compared to all other varieties under test (Table 3). The variety C 306 showed its superiority in most of the yield contributing hence, better grain yield variety C 306 over rest of the varieties. These results are in conformity with the results of Singh et al. (2010) ${ }^{[7]}$ Mauriya et al. (2015) ${ }^{[3]}$ and Singh (2015) ${ }^{[8]}$.

From the results of this experiment, it can be concluded that for grid region of Northern Madhya Pradesh growing of wheat variety $\mathrm{C}-306$ with $80 \mathrm{Kg} \mathrm{Nha}^{-1}$ gives higher grain yield under conserved moisture conditions.

Table 1: Plant height, number of tillers and days to maturity as influenced by levels of nitrogen and varieties of wheat

\begin{tabular}{|c|c|c|c|}
\hline Treatments & Number of tillers per $m$ row length at harvest & Plant height at harvest, cm & Days to maturity, no \\
\hline \multicolumn{4}{|c|}{ Levels of Nitrogen $\mathrm{Kg} \mathrm{ha}^{-1}$} \\
\hline 40 & 68.50 & 59.02 & 145.2 \\
\hline 60 & 71.28 & 62.88 & 150.5 \\
\hline 80 & 74.82 & 64.79 & 153. \\
\hline S. Em.土 & 1.07 & 1.15 & 0.9 \\
\hline C.D. at $5 \%$ & 3.70 & 3.97 & 3.1 \\
\hline \multicolumn{4}{|c|}{ Varieties } \\
\hline PBW 613 & 71.94 & 66.62 & 153.2 \\
\hline C $306(\mathrm{C})$ & 74.94 & 66.97 & 154.1 \\
\hline PBW 644 & 69.25 & 52.62 & 145.3 \\
\hline PBW 660 & 70.00 & 62.72 & 145.7 \\
\hline S. Em. \pm & 0.96 & 1.09 & 1.0 \\
\hline C.D. at $5 \%$ & 2.78 & 66.62 & 2.8 \\
\hline
\end{tabular}

Table 2: Yield attributing characters as influenced by levels of nitrogen and varietiesof wheat

\begin{tabular}{|c|c|c|c|c|c|c|}
\hline Treatments & $\begin{array}{c}\text { Number of Ear head } \mathrm{m}^{-} \\
{ }^{1} \text { row length }\end{array}$ & $\begin{array}{l}\text { Spike length } \\
(\mathrm{cm})\end{array}$ & $\begin{array}{c}\text { Number of } \\
\text { spikelets spike }^{-1}\end{array}$ & $\begin{array}{l}\text { Number of } \\
\text { grains ear }^{-1}\end{array}$ & $\begin{array}{c}\text { Grain weight } \\
\text { Spike }^{-1}(\mathrm{~g})\end{array}$ & $\begin{array}{c}\text { 1000-grains } \\
\text { weight (g) }\end{array}$ \\
\hline \multicolumn{7}{|c|}{ Levels of Nitrogen $\mathrm{kg} \mathrm{ha}^{-1}$} \\
\hline 40 & 60.37 & 5.85 & 11.08 & 26.18 & 2.28 & 29.50 \\
\hline 60 & 66.83 & 6.48 & 12.75 & 28.67 & 2.84 & 29.15 \\
\hline 80 & 69.54 & 6.93 & 13.67 & 30.25 & 3.02 & 28.67 \\
\hline S. Em.土 & 1.02 & 0.16 & 0.36 & 0.50 & 0.15 & 0.20 \\
\hline C.D. at $5 \%$ & 3.54 & 0.54 & 1.26 & 1.74 & 0.53 & 0.68 \\
\hline \multicolumn{7}{|c|}{ Varieties } \\
\hline PBW 613 & 67.16 & 6.52 & 12.75 & 28.89 & 2.78 & 29.63 \\
\hline C $306(\mathrm{C})$ & 68.80 & 6.65 & 12.98 & 29.33 & 2.94 & 30.12 \\
\hline PBW 644 & 62.24 & 6.12 & 11.97 & 27.29 & 2.44 & 27.54 \\
\hline PBW 660 & 64.12 & 6.37 & 12.30 & 27.96 & 2.70 & 29.13 \\
\hline S. Em. \pm & 1.20 & 0.06 & 0.11 & 0.16 & 0.07 & 0.19 \\
\hline C.D. at $5 \%$ & 3.49 & 0.16 & 0.32 & 0.46 & 0.21 & 0.54 \\
\hline
\end{tabular}

Table 3: Grain yield $\left(\mathrm{kg} \mathrm{ha}^{-1}\right)$, Straw yield $\left(\mathrm{kg} \mathrm{ha}^{-1}\right)$, Biological yield $\left(\mathrm{kg} \mathrm{ha}^{-1}\right)$ and Harvest index (\%) of wheat crop as influenced by various treatments

\begin{tabular}{|c|c|c|c|c|}
\hline Treatments & Biological yield $\left(\mathrm{kg} \mathrm{ha}^{-1}\right)$ & Grain yield $\left(\mathrm{kg} \mathrm{ha}^{-1}\right)$ & Straw yield $\left(\mathrm{kg} \mathrm{ha}^{-1}\right)$ & Harvest index (\%) \\
\hline \multicolumn{5}{|c|}{ Levels of Nitrogen $\mathrm{Kg} \mathrm{ha}^{-1}$} \\
\hline 40 & 7573 & 3065 & 4508 & 40.47 \\
\hline 60 & 7897 & 3253 & 4644 & 41.19 \\
\hline 80 & 8196 & 3396 & 4800 & 41.43 \\
\hline S. Em. \pm & 89 & 42 & 077 & 0.23 \\
\hline C.D. at $5 \%$ & 309 & 146 & 265 & 0.78 \\
\hline \multicolumn{5}{|c|}{ Varieties } \\
\hline PBW 613 & 8009 & 3263 & 4746 & 40.74 \\
\hline $\mathrm{C}-306(\mathrm{C})$ & 8167 & 3398 & 4769 & 41.61 \\
\hline PBW 644 & 7574 & 3109 & 4465 & 41.05 \\
\hline PBW 660 & 7805 & 3183 & 4622 & 40.78 \\
\hline S. Em.土 & 50 & 40 & 21 & 0.31 \\
\hline C.D. at $5 \%$ & 144 & 115 & 62 & NS \\
\hline
\end{tabular}




\section{References}

1. Jat SL, Nepalia V, Choadhary J, Singh D. Effect of nitrogen and weed management on productivity and quality of durum wheat (Triticum aestivum). Indian Journal of Agronomy. 2014; 59(2):281-285.

2. Kachroo D, Razdan R. Growth, nutrient uptake and yield of wheat (Triticum aestivum L.) as influenced by biofertilizers and nitrogen. Indian Journal of Agronomy. 2006; 51(1):37-39.

3. Mauriya AK, Maurya DC, Maurya VK, Verma RK. Effect of zinc application methods on yield attributes, yield and nutrient uptake in wheat (Triticum aestivum L.) varieties under sodic soil. Indian Journal of Agronomy. 2015; 60(1):82-86.

4. Panse VG, Sukhatme PV. Statistical method for agricultural workers. I.C.A.R., New Delhi, 1967.

5. Phogat, Mal Todar, Kumar SB, Bhagat, Satish Singh. Effect of nitrogen on yield and quality of barley (Hordeum vulgare L.) genotypes. Indian Journal of Agronomy. 2014; 59(1):171-174.

6. Puniya MM, Yadav SS, Shivran AC. Productivity, profitability and nitrogen- use efficiency of barley (Hordeum valgare) as influenced by weed management and nitrogen fertilization under hot semi-arid ecologies of Rajathan. Indian Journal of Agronomy. 2015; 60(4):564-569. Shah et al. 2011

7. Singh P, Singh KN, Singh R, Aga FA, Bahar F, Waseem Raja. Evaluation of wheat (Triticum aestivum L.) genotypes for productivity and economics under graded levels of nitrogen in temperature Kashmir. Indian Journal of Agricultural Sciences. 2010; 80(5):380-384.

8. Singh Satpal. Response of wheat genotypes to nitrogen under rainfed conditions. International Journal of Food, Agriculture and Veterinary Sciences. 2015; 5(2):82-85.

9. Yadav AK, Chauhan SK, Shroti SK. Effect of date of sowing and levels of nitrogen on yield, yield attributes and economies of vegetable pea in vegetable pea-wheatmaize cropping system. Ann. Pl. Soil Res. 2012; 14(2):159-162. 